\title{
PPAR $\gamma$ Pro12Ala and C161T polymorphisms, but not PPAR $\alpha$ L162V, are associated with osteoporosis risk in Turkish postmenopausal women
}

\author{
Özlem Kurt Șirin',* (D), Hülya Yılmaz Aydoğan² (D), Mehmet Uyar³ (D), Ayșe Can ${ }^{1}$ (D) \\ 'Department of Biochemistry, Faculty of Pharmacy, Istanbul University, 34116, Istanbul, Turkey \\ ${ }^{2}$ Department of Molecular Medicine, Aziz Sancar Institute of Experimental Medicine, 34390, Istanbul University, Istanbul, \\ Turkey \\ ${ }^{3}$ Department of Phsycial Medicine and Rehabilitation, Uskudar State Hospital, 34662, Istanbul, Turkey
}

ORCID IDs of the authors: 0.K.S. 0000-0001-9532-6609, H.Y.A. 0000-0002-8837-6664, M.U. 0000-0003-4376-0256, A.C. 00000002-8538-663X.

Cite this article as: Kurt Șirin Ö, Yılmaz Aydoğan H, Uyar M, Can A (2019). PPAR Pro12Ala and C161T polymorphisms, but not PPAR $\alpha$ L162V, are associated with osteoporosis risk in Turkish postmenopausal women. Istanbul J Pharm 49 (1): 14-19.

\begin{abstract}
Stimulation of peroxisome proliferator-activated receptors (PPARS) causes mesenchymal stem cells of the human bone marrow differentiate into adipocytes instead of osteoblasts leading to a decreased number of osteoblasts and a decrease in bone mineral density (BMD). Thus, PPARs may have impacts on bone metabolism. 224 postmenopausal women (171 osteoporotic and osteopenic, 53 healthy control) were included in this study. Polymerase chain reaction-restriction fragment length polymorphism (PCR-RFLP) and agarose gel electrophoresis techniques were performed to detect PPAR $\alpha$ L162V and PPAR Pro12Ala/C161T polymorphisms. The distribution of PPAR Pro12Ala genotype and allele frequencies was not statistically different in control and patient (osteopenic+osteoporotic) groups ( $p>0.05$ ). However, in the patient group, subjects with "Pro12Pro" genotype had lower lumbar spine (L1-L4) BMD values than those with "Ala" allele ( $<<0.05)$. The frequency of PPAR C161T "CC" genotype was higher in the patient group when compared with that in the control group ( $<<0.05)$. There were no significant associations between the genotype and allele frequencies of PPAR C 161T/ PPAR $\alpha$ L162V and BMD values ( $p>0.05$ ). We suggested that PPAR Pro12Ala and C161T gene variants might be contributing factors in the development of osteoporosis.

Keywords: Peroxisome proliferator-activated receptor, bone mineral density, osteoporosis, polymorphism
\end{abstract}

\section{INTRODUCTION}

Peroxisome proliferator-activated receptors (PPARs) belong to the superfamily of nuclear receptors which are are ligand-activated transcription factors. Three different PPAR subtypes have been identified; PPARa, PPARß (also called PPARS), and PPARY (Abbot 2009). PPARa is found in tissues such as heart, muscle, liver and kidney where fatty acid catabolism is important and so regulates genes involved in lipid metabolism. PPARa is activated by natural ligands (polyunsaturated fatty acids, lipolytic products of lipoproteins, oxidized phospholipids) and by synthetic ligands (gemfibrozil and fenofibrate) (Touyz and Schiffrin 2006). Fenofibrate which is currently used for the treatment of hypercholesterolemia and hypertriglyceridemia, also maintains bone mass. Whole body and femoral bone mineral density (BMD) values were higher in ovariectomized rats given fenofibrate, compared to controls (Stunes et al. 2011).

PPARY is heavily expressed in adipose tissue and controls adipocyte differentiation and lipid storage. PPARY regulates the action of insulin through its effects on adipose tissue and skeletal muscle (Touyz and Schiffrin 2006). Natural agonists (eicosanoids and oxidized, polyunsaturated fatty acids) and synthetic agonists (thiazolidinediones; a family of antidiabetic drugs-rosiglitazone and 
pioglitazone) for PPARY decrease peripheral insulin resistance and thereby reduce blood glucose levels in type 2 diabetic patients (Touyz and Schiffrin 2006; Harsløf et al. 2011). After activation of PPARY by rosiglitazone, mesenchymal stem cells differentiate into adipocytes instead of osteoblasts leading to increased number of adipocytes and decreased number of osteoblasts and decreased BMD in mouse bone marrow (Rzonca et al. 2004; Ali et al. 2005).

To date, several polymorphisms within the human PPARa gene have been identified. Of these, a $\mathrm{C} \rightarrow \mathrm{G}$ transversion at position 484 in exon 5, leading to a substitution of valine for leucine (L162V) at codon 162, has functional effects on PPARa activity (Flavell et al. 2002; Do et al. 2009). Some studies have found associations between PPARa L162V polymorphism and plasma lipids and atherosclerosis development, however, the effects of this polymorphism on bone metabolism haven't been investigated so far.

Cytosine-guanine exchange in exon B (codon12) is the most common gene mutation in human PPARY gene resulting proline (Pro) to alanine (Ala) substitution in the protein (TemelkovaKurktschiev et al. 2004). C161T substitution in exon 6 of the PPARY gene was also described (Meirhaeghe et al. 1998). PPARY was found to be related with cardiovascular diseases (Takano and Komuro, 2009), diabetes mellitus (Cho et al. 2008), carcinogenesis (Elrod and Sun 2008) and inflammation (Kapoor et al. 2007a; 2007b; Szanto and Nagy 2008) in some studies. PPARy was also associated with bone mineral density, osteoporosis, osteoarthritis and non-traumatic hip fracture risk in various populations (Ogawa et al. 1999; Harslof et al. 2010; Tamaki et al. 2010; Fahmi et al. 2011; Dragojevič et al. 2011; Wang et al. 2013). However, no association was found between PPARY and bone mineral density variation in Chinese nuclear families (Yue at al. 2010) and in Japanese postmenopausal women (Wang et al. 2013).

To the best of our knowledge, there is no study regarding the association of PPARa polymorphisms with BMD and osteoporosis. Little is known about the association of the PPARY polymorphism with the osteoporosis risk and also the results are controversial. Therefore, we aimed to investigate the relation between PPARa and PPARY gene variants and osteoporosis in Turkish postmenopausal women.

\section{MATERIALS AND METHODS}

\section{Subjects}

224 Turkish postmenopausal women (171 osteoporotic and osteopenic, 53 healthy control), attending the Uskudar State Hospital in Istanbul were recruited in this study. World Health Organization (WHO) definitions and criteria for osteopenia and osteoporosis were used during ascertainment (World Health Organization Study Group, 1994). The patients received a standardized questionnaire including questions regarding the osteoporosis risk factors (age, menopausal status, smoking, family history of osteoporosis), medication use and other medical conditions. Demographic and morphometric characteristics were also recorded. Subjects with a clinical diagnosis of osteopenia/osteoporosis and those with normal BMD values were included in the study group. Exclusion criteria were conditions, diseases, and/ or treatments known to interfere with bone metabolism, such as malignancies, severe liver or gastroenteral diseases, endocrinologic disorders (hypo-hyperparathyroidism, hyperthyroidism, Cushing's syndrome), skeletal diseases (rheumatoid arthritis, osteomalacia, osteogenesis imperfecta and Paget's disease) and current pharmacological treatment with anabolic androgenic steroids, estrogens or estrogen-related molecules, corticosteroids and anticonvulsants before enrollment. Menopause was defined as amenorrhoea of at least one year duration. The study protocol was approved by the Local Ethical Commitee of Istanbul University, Istanbul Medical Faculty (Protocol No: 2006/2145). All participants signed written, informed consent forms prior to giving their blood sample.

\section{BMD measurement}

Dual energy X-ray absorptiometry (DXA; Lunar DPX (GE Lunar Corporation, Madison, WI, USA) was used to determine BMD of the lumbar spine (L1-L4) and hip (femoral neck and total hip). All DEXA scans were analyzed according to software (encore version 2005, 9.30.044) provided by the manufacturer. BMD was expressed as grams per centimeter square $\left(\mathrm{g} / \mathrm{cm}^{2}\right)$.

\section{Genotype study}

Genomic DNA samples were extracted from whole blood with salting out procedure (Miller et al. 1988). Polymerase chain reaction-restriction fragment lenght polymorphism (PCR-RFLP) analysis were used to detect PPARa L162V and PPARYPro12Ala/ C161T polymorphisms as previously reported (Yen et al. 1997; Flavell et al. 2002).

\section{Statistical analysis}

The statistical analysis was performed using Statistical Package for Social Sciences (SPSS) software package programme version 20.0 (IBM Corp., Armonk, NY, USA). Categorical variables are presented as frequencies, while continous variables are presented as means ( \pm standard deviation-S.D.). Chi-square $\left(x^{2}\right)$ test was used for genotype and allele frequencies comparison and Hardy-Weinberg Equilibrium (HWE). BMD values of different genotypes and alleles were compared by Student's t-test. Allele frequencies were calculated by gene counting method. Values of $p<0.05$ were considered statistically significant.

\section{RESULTS}

\section{Demographic characteristics and BMD status}

The baseline characteristics of the study population were presented in Table 1. As expected, the body mass index (BMI), BMD values of lumbar spine (L1-L4), femoral neck and total hip showed significant differences between control and patient (osteopenic+osteoporotic) groups $(p<0.001)$, whereas no significant differences were detected in age, age of menopause, smoking and family history of osteoporosis ( $p>0.05$ ).

\section{PPARY Pro12Ala/C161T and PPARa L162V genotypes and allele distribution}

The genotypic and allelic frequencies of PPARY Pro12Ala/ C161T and PPARa L162V polymorphisms were shown in Table 2. PPARY C161T "CC" genotype frequency was found to be higher in the patient group when compared to that in the control group ( $p=0.028$ ). No significant differences were found in the frequencies of PPARY Pro12Ala and PPARa L162V 
genotypes and alleles within two groups (p>0.05). "Ala12Ala", "TT" and "VV" genotypes were not observed in the control group.

\section{The association of PPARY and PPARa polymorphisms with BMD values}

The association of PPARY Pro12Ala/C161T and PPARa L162V genotypes with BMD values were presented in Table 3. In the patient group, subjects with "Pro12Pro" genotype had lower lumbar spine (L1-L4) BMD values than those with "Ala" allele $(\mathrm{p}<0.05)$. No significant association was found between PPARY C161T and PPARa L162V genotypes and BMD values in the study groups ( $p>0.05)$.

\section{DISCUSSION}

The present study is the first one in Turkish population showing an association between PPARY gene and the risk of the development of osteoporosis. Subjects with PPARY "Pro12Pro" genotype had lower lumbar spine BMD values than those with "Ala" allele in our patient group. Similarly, in a study with

\section{Table 1. The baseline characteristics of the study population}

\begin{tabular}{|c|c|c|}
\hline & Control $n=53$ & Patient $n=171$ \\
\hline Age & $55.55 \pm 6.99$ & $57.24 \pm 5.99$ \\
\hline Age of menopause & $46.47 \pm 5.17$ & $46.50 \pm 5.13$ \\
\hline BMI $\left(\mathrm{kg} / \mathrm{m}^{2}\right)$ & $33.22 \pm 5.11$ & $29.52 \pm 4.83^{*}$ \\
\hline Smoking (n, \%) & $5(9.4 \%)$ & $17(9.9 \%)$ \\
\hline $\begin{array}{l}\text { Family history of } \\
\text { osteoporosis (n, \%) }\end{array}$ & $24(47.1 \%)$ & $74(43.3 \%)$ \\
\hline $\begin{array}{l}\text { Lumbar spine } \\
(\mathrm{L} 1-\mathrm{L} 4) \mathrm{BMD}\left(\mathrm{g} / \mathrm{cm}^{2}\right)\end{array}$ & $1.183 \pm 0.110$ & $0.940 \pm 0.113^{*}$ \\
\hline Femoral neck BMD $\left(\mathrm{g} / \mathrm{cm}^{2}\right)$ & $0.966 \pm 0.101$ & $0.827 \pm 0.088^{*}$ \\
\hline Total hip BMD $\left(\mathrm{g} / \mathrm{cm}^{2}\right)$ & $1.044 \pm 0.099$ & $0.882 \pm 0.093^{*}$ \\
\hline \multicolumn{3}{|c|}{$\begin{array}{l}\mathrm{n} \text { : number of subjects, } \mathrm{BMI} \text { : Body mass index, BMD: Bone mineral } \\
\text { density. } \\
\text { Values are means } \pm S D \text { except where noted. } \\
* \mathrm{p}<0.001 \text { vs. control group. }\end{array}$} \\
\hline
\end{tabular}

$\beta$-thalassemia major patients, the risk of osteopenia was significantly higher in subjects with "Pro12Pro" genotype than the carriers of the rare alleles (Sahmani et al. 2013). In contrast to our results, postmenopausal women with "Pro12Pro" genotype had higher BMD of lumbar spine than that of subjects with "Pro12Ala" genotype (Yue et al. 2010). PPARY Pro12Ala gene variants were not associated with BMD in elderly and young Swedish women (Herlin et al. 2015). Also, PPARy Pro12Ala was not independently associated with BMD values in postmenopausal Japanese women, either (Wang et al. 2013). We think

\section{Table 2. The distribution of PPAR $\gamma$ Pro12Ala/ C161T and PPAR $\alpha$ L162V genotypes and allele frequencies in the study groups}

\begin{tabular}{|c|c|c|}
\hline Genotypes / Alleles & Control n, $(\%)$ & Patient $\mathrm{n},(\%)$ \\
\hline \multicolumn{3}{|l|}{ PPAR $\gamma$ Pro12Ala } \\
\hline Pro12Pro & $42(79.2 \%)$ & 149 (87.1\%) \\
\hline Pro12Ala & $11(20.8 \%)$ & $20(11.7 \%)$ \\
\hline Ala12Ala & $0(0 \%)$ & $2(1.2 \%)$ \\
\hline Pro & $95(89.6 \%)$ & $318(93 \%)$ \\
\hline Ala & $11(10.4 \%)$ & $24(7 \%)$ \\
\hline \multicolumn{3}{|l|}{ PPAR C $161 \mathrm{~T}$} \\
\hline $\mathrm{CC}$ & $37(69.8 \%)$ & $142(83 \%)^{*}$ \\
\hline CT & $16(30.2 \%)$ & $24(14 \%)$ \\
\hline TT & $0(0 \%)$ & $5(3 \%)$ \\
\hline C & $90(84.9 \%)$ & $308(90.1 \%)$ \\
\hline $\mathrm{T}$ & $16(15.1 \%)$ & $34(9.9 \%)$ \\
\hline \multicolumn{3}{|l|}{$P P A R \alpha \mathrm{L} 162 \mathrm{~V}$} \\
\hline LL & $39(73.6 \%)$ & $116(67.8 \%)$ \\
\hline LV & $14(26.4 \%)$ & $50(29.2 \%)$ \\
\hline VV & $0(0 \%)$ & $5(2.9 \%)$ \\
\hline $\mathrm{L}$ & $92(86.8 \%)$ & 282 (82.5\%) \\
\hline V & $14(13.2 \%)$ & $60(17.5 \%)$ \\
\hline \multicolumn{3}{|c|}{$\begin{array}{l}\text { n: number of subjects, PPAR } \gamma: \text { Peroxisome proliferator activated } \\
\text { receptor gamma, PPAR } \alpha \text { : Peroxisome proliferator activated } \\
\text { receptor alpha } \\
* \text { p }<0.05 \text { vs. control group. }\end{array}$} \\
\hline
\end{tabular}

Table 3. Association of PPAR $\gamma$ and PPAR $\alpha$ genotypes with BMD values in study population

\begin{tabular}{|c|c|c|c|c|c|c|}
\hline \multirow[b]{2}{*}{ Groups/BMD } & \multicolumn{2}{|c|}{ PPAR $\gamma$ Pro12Ala } & \multicolumn{2}{|c|}{ PPAR $\gamma \mathrm{C} 161 \mathrm{~T}$} & \multicolumn{2}{|c|}{ PPAR $\alpha$ L162V } \\
\hline & Pro12Pro & Pro12Ala +Ala12Ala & $\mathrm{CC}$ & $\mathrm{CT}+\mathrm{TT}$ & LL & $L V+V V$ \\
\hline \multicolumn{7}{|l|}{ Control } \\
\hline Lumbar spine & $1.190 \pm 0.115$ & $1.160 \pm 0.087$ & $1.190 \pm 0.119$ & $1.170 \pm 0.089$ & $1.170 \pm 0.075$ & $1.230 \pm 0.171$ \\
\hline Femoral neck & $0.974 \pm 0.110$ & $0.934 \pm 0.049$ & $0.976 \pm 0.116$ & $0.943 \pm 0.053$ & $0.968 \pm 0.103$ & $0.960 \pm 0.101$ \\
\hline Total hip & $1.064 \pm 0.101$ & $0.990 \pm 0.048$ & $1.062 \pm 0.107$ & $1.006 \pm 0.069$ & $1.038 \pm 0.091$ & $1.061 \pm 0.124$ \\
\hline \multicolumn{7}{|l|}{ Patient } \\
\hline Lumbar spine & $0.940 \pm 0.114^{*}$ & $0.990 \pm 0.082$ & $0.940 \pm 0.114$ & $0.950 \pm 0.103$ & $0.940 \pm 0.111$ & $0.940 \pm 0.115$ \\
\hline Femoral neck & $0.825 \pm 0.084$ & $0.850 \pm 0.091$ & $0.828 \pm 0.084$ & $0.833 \pm 0.093$ & $0.822 \pm 0.088$ & $0.841 \pm 0.079$ \\
\hline Total hip & $0.883 \pm 0.090$ & $0.892 \pm 0.094$ & $0.882 \pm 0.089$ & $0.895 \pm 0.095$ & $0.881 \pm 0.094$ & $0.890 \pm 0.082$ \\
\hline \multicolumn{7}{|c|}{$\begin{array}{l}\text { BMD: Bone mineral density, PPAR } \text { : Peroxisome proliferator activated receptor gamma, PPAR } \alpha \text { : Peroxisome proliferator activated receptor } \\
\text { alpha }\end{array}$} \\
\hline
\end{tabular}


that these results differ depending on geographic background and number of subjects in the studies.

In our study, PPARY C161T"CC" genotype frequency was found to be higher in the patient group when compared with the control group, however, no association was found between the C161T genotypes and BMD values. In contrast, $Z$ scores of the lumbar and total body BMD was found to be higher in Japanese postmenopausal women with PPARY C161T "CC" genotype than those in the subjects with " $\mathrm{CT}+\mathrm{TT}$ " genotype. It was suggested that there is an association between PPARY gene and BMD and the possible involvement of C161T polymorphism in the cause of postmenopausal osteoporosis in Japanese women (Ogawa et al. 1999). Femoral neck and total hip BMD values were significantly higher in Japanese premenopausal women with "CC" genotype than the values in subjects with "CT/TT" genotypes (Tamaki et al. 2010). Similar to our results, no association was found between PPARY C161T genotypes and BMD of lumbar spine/femoral neck in healthy Korean pre- and postmenopausal women (Rhee et al. 2005).

An association was found between polymorphisms in PPARY, $\mathrm{BMD}$ and fracture risk in Danish population indicating that the effect may be modified by environmental factors (Harsløf et al. 2011). Besides, PPARY Pro12Ala and C161T polymorphisms did not have any significant relation with the non-traumatic hip fracture risk in the elderly Slovenian population (Dragojevič et al. 2011)

In the present study, the frequencies of "Ala" allele were 10.4\% and $7 \%$ in the control and in the patient groups, respectively. C161T"rare allele (T)"frequency was 15.1\% in the control group versus $9.9 \%$ of the patient group. "Ala12Ala" and "TT" genotypes were not observed in the control group (0\%) whereas the frequencies of them were $1.2 \%$ and $3 \%$ in the patient group, respectively. The genotype populations of PPARy Pro12Ala/C161T were in accordance with those in Turkish patients with inflammatory bowel disease, coronary heart disease and gastric cancer (Atug et al. 2008; Yilmaz-Aydogan et al. 2011; Canbay et al. 2012). Similar to our results, Erdogan et al. (2007) reported the frequency as 0\% for "Ala12Ala" genotype in the control group and in diabetic patients with and without diabetic nefropathy. However, in their study, the frequency for "Ala" allele was found as $0 \%$ and $0.5 \%$ in control group and in diabetic group, respectively. A remarkable difference was observed in their study in terms of "Ala" allele distribution. This observed difference may be based on the different number of healthy controls and patients in these two studies. Also the different patient group of Erdogan's study consisting diabetic subjects may affect the allelic differences between the two studies. Similar to our results, "T" allele frequencies were found as 11.5 and 9.3 in control and patient group in Erdogan's study.

Pro12Ala and C161T frequencies in our study are similar to those in Slovenian population (Dragojevič et al. 2011) and those in Chinese postmenopausal women (Yue at al. 2010). The genotype and allelic frequencies of Pro12Ala was also found to be similar to our results in a meta-analysis study with European Caucasion population (Zhang et al. 2012) and in studies with
Japanese postmenopausal women (Ogawa et al. 1999; Wang et al. 2013). Pro12Ala genotype and allelic frequencies in two studies with Iranian population are similar to the frequencies in the present study, however, they could not find any subjects with "Ala12Ala" genotype in their study (Namvaran et al. 2011; Sahmani et al. 2013). C161T frequencies in Japanese women (Tamaki et al. 2010) and Korean women (Rhee et al. 2005) are in accordance with our results.

As of now, there isn't any study showing a relation between PPARa L162V polymorphism, BMD and the risk of osteoporosis. However, no significant association was found between PPARa L162V genotype and allele frequencies and BMD values in our study population. The genotype and allele frequencies of PPARa L162V are similar to those in a previous Turkish study with coronary heart disease based on the presence of diabetes (Yilmaz-Aydogan et al. 2013) and to those in another study with Turkish subjects (Koytak et al. 2008). Besides, our frequencies differ from those found in Spanish Mediterranean, Brazilian and Croatian populations (Francès et al. 2008; Chen et al. 2010; Nadalin et al. 2014). "VV" genotype was not found in Croatian population (Nadalin et al. 2014) and in multi-ethnic Malaysian population (Chia et al. 2015). Similarly we found no subjects with "VV" genotype in our control group whereas we found only five subjects in our patient group.

The frequencies of Pro12Ala-Ala12Ala genotype, C161T-TT genotype and L162V-V genotype are very rarely observed in the present study. Therefore, ANOVA statistical test couldn't be used for the comparison of genotypes and BMD values. Furthermore, this report was comprised of a relatively small study population. These represents the limitations of the study. We think that further studies with higher number of subjects may be necessary to conclude with greater certainty of the relation between PPARY Pro12Ala/C161T polymorphisms and decreased BMD status.

\section{CONCLUSION}

The present study suggests that PPARY Pro12Ala and C161T polymorphisms may contribute to the development of osteoporosis in Turkish postmenopausal women.

Ethics Committee Approval: The study protocol was approved by the Local Ethical Commitee of Istanbul University, Istanbul Medical Faculty (Protocol No: 2006/2145).

Informed Consent: All participants signed written, informed consent forms prior to giving their blood sample.

Peer-review: Externally peer-reviewed.

Author Contributions: Concept - O.K.S., H.Y.A. ; Design - O.K.S., H.Y.A. M.U. ; Supervision - O.K.S., H.Y.A., A.C. ; Resource - O.K.S., H.Y.A., M.U. ; Materials - O.K.S., H.Y.A., M.U. ; Data Collection and/or Processing O.K.S., H.Y.A., M.U. ; Analysis and/or Interpretation - O.K.S., H.Y.A., M.U. A.C.; Literature Search - O.K.S., H.Y.A. ; Writing - O.K.S., H.Y.A., A.C.; Critical Reviews - O.K.S., H.Y.A., A.C.

Conflict of Interest: The authors have no conflict interest to declare. 
Financial Disclosure: This study was funded by Scientific Research Projects Coordination Unit of Istanbul University (Project No: 17622).

\section{REFERENCES}

- $\quad$ Abbott BD (2009). Review of the expression of peroxisome proliferator-activated receptors alpha (PPAR alpha), beta (PPAR beta), and gamma (PPAR gamma) in rodent and human development. Reprod Toxicol 27: 246-257. [CrossRef]

- $\quad$ Ali AA, Weinstein RS, Stewart SA, Parfitt AM, Manolagas SC, Jilka RL (2005). Rosiglitazone causes bone loss in mice by suppressing osteoblast differentiation and bone formation. Endocrinology 146: 1226-1235. [CrossRef]

- $\quad$ Atug O, Tahan V, Eren F, Tiftikci A, Imeryuz N, Hamzaoglu HO, Tozun N (2008). Pro12Ala polymorphism in the peroxisome proliferator-activated receptor-gamma (PPARgamma) gene in inflammatory bowel disease. J Gastrointestin Liver Dis 17: 433-437.

- Canbay E, Kurnaz O, Canbay B, Bugra D, Cakmakoglu B, Bulut T, Yamaner S, Sokucu N, Buyukuncu Y, Yilmaz-Aydogan H (2012). PPAR-gamma Pro12Ala polymorphism and gastric cancer risk in a Turkish population. Asian Pac J Cancer Prev 13: $5875-5878$. [CrossRef]

- Chen ES, Mazzotti DR, Furuya TK, Cendoroglo MS, Ramos LR, Araujo LQ, Burbano RR, Smith Mde A (2010). Association of PPARalpha gene polymorphisms and lipid serum levels in a Brazilian elderly population. Exp Mol Pathol 88: 197-201. [CrossRef]

- Chia PP, Fan SH, Say YH (2015). Screening of Peroxisome Proliferator-Activated Receptors (PPARs) $a, y$ and a Gene Polymorphisms for Obesity and Metabolic Syndrome Association in the MultiEthnic Malaysian Population. Ethn Dis 25: 383-390. [CrossRef]

- Cho MC, Lee K, Paik SG, Yoon DY (2008). Peroxisome ProliferatorsActivated Receptor (PPAR) Modulators and Metabolic Disorders. PPAR Res 2008: 679137. [CrossRef]

- Do HQ, Nazih H, Luc G, Arveiler D, Ferrières J, Evans A, Amouyel P, Cambien F, Ducimetière P, Bard JM (2009). Influence of cholesteryl ester transfer protein, peroxisome proliferator-activated receptor a, apolipoprotein $\mathrm{E}$, and apolipoprotein A-I polymorphisms on highdensity lipoprotein cholesterol, apolipoprotein A-I, lipoprotein A-I, and lipoprotein A-I:A-II concentrations: the Prospective Epidemiological Study of Myocardial Infarction study. Metabolism 58: 283-289. [CrossRef]

- Dragojevič J, Ostanek B, Mencej-Bedrač S, Komadina R, Preželj J, Marc J (2011). PPARG gene promoter polymorphism is associated with non-traumatic hip fracture risk in the elderly Slovenian population: a pilot study. Clin Biochem 44: 1085-1089. [CrossRef]

- Elrod HA, Sun SY (2008). PPARgamma and apoptosis in cancer. PPAR Res 2008: 704165. [CrossRef]

- Erdogan M, Karadeniz M, Eroglu Z, Tezcanli B, Selvi N, Yilmaz C (2007). The relationship of the peroxisome proliferator-activated receptor-gamma 2 exon 2 and exon 6 gene polymorphism in Turkish type 2 diabetic patients with and without nephropathy. Diabetes Res Clin Pract 78: 355-359. [CrossRef]

- Fahmi H, Martel-Pelletier J, Pelletier JP, Kapoor M (2011). Peroxisome proliferator-activated receptor gamma in osteoarthritis. Mod Rheumato/ 21: 1-9. [CrossRef]

- Flavell DM, Jamshidi Y, Hawe E, Torra IP, Taskinen MR, Frick MH, Nieminen MS, Kesäniemi YA, Pasternack A, Staels B, Miller G, Humphries SE, Talmud PJ, Miller G (2002). Peroxisome proliferatoractivated receptor alpha gene variants influence progression of coronary atherosclerosis and risk of coronary artery disease. Circulation 105: 1440-1445. [CrossRef]

- Francès F, Verdú F, Portolés O, Castelló A, Sorlí JV, Guillen M, Corella D (2008). PPAR-alpha L162V and PGC-1 G482S gene polymorphisms, but not PPAR-gamma P12A, are associated with alcohol consumption in a Spanish Mediterranean population. Clin Chim Acta 398: 70-74. [CrossRef]

- HarsløfT, Tofteng CL, Husted LB, Nyegaard M, Børglum A, Carstens M, Stenkjær L, Brixen K, Eiken P, Jensen JE, Mosekilde L, Rejnmark $L$, Langdahl BL (2011). Polymorphisms of the peroxisome proliferator-activated receptor $\gamma$ (PPARY) gene are associated with osteoporosis.Osteoporos Int 22: 2655-2666. [CrossRef]

Herlin M, McGuigan FE, Luthman H, Åkesson K (2015). Polymorphisms in inflammation associated genes ALOX15 and IL-6 are associated with bone properties in young women and fracture in elderly. Bone 79: 105-109. [CrossRef]

- Kapoor M, Kojima F, Qian M, Yang L, Crofford L (2007a). Microsomal prostaglandin E synthase-1 deficiency is associated with elevated peroxisome proliferator-activated receptor gamma: regulation by prostaglandin E2 via the phosphatidylinositol 3-kinase and Akt pathway. J Biol Chem 282: 5356-5366. [CrossRef]

Kapoor M, Kojima F, Yang L, Crofford LJ (2007b). Sequential induction of pro- and anti-inflammatory prostaglandins and peroxisome proliferators-activated receptor-gamma during normal wound healing: a time course study. Prostaglandins Leukot Essent Fatty Acids 76: 103-112. [CrossRef]

Koytak ES, Mizrak D, Bektaş M, Verdi H, Ergül AA, Idilman R, Çınar K, Yurdaydın C, Ersöz S, Karayalçın K, Uzunalimoğlu Ö, Bozkaya H (2008). PPAR-alpha L162V polymorphism in human hepatocellular carcinoma. Turk J Gastroenterol 19: 245-249.

- Meirhaeghe A, Fajas L, Helbecque N, Cottel D, Lebel P, Dallongeville J, Deeb S, Auwerx J, Amouyel P (1998). A genetic polymorphism of the peroxisome proliferator-activated receptor gamma gene influences plasma leptin levels in obese humans. Hum Mol Genet 7: 435-440. [CrossRef]

Miller SA, Dykes DD, Poleskey HS (1998). Simples salting out procedure for extracting DNA from human nucleated cells. Nucleic Acids Res 16: 1215. [CrossRef]

Nadalin S, Giacometti J, Buretić-Tomljanović A (2014). PPARaL162V polymorphism is not associated with schizophrenia risk in a Croatian population. Prostaglandins Leukot Essent Fatty Acids 91: 221-225. [CrossRef]

- Namvaran F, Rahimi-Moghaddam P, Azarpira N (2011). Genotyping of peroxisome proliferator-activated receptor gamma (PPAR- $\gamma$ ) polymorphism (Pro12Ala) in Iranian population. J Res Med Sci 16: 291-296.

Ogawa S, Urano T, Hosoi T, Miyao M, Hoshino S, Fujita M, Shiraki M, Orimo H, Ouchi Y, Inoue S (1999). Association of bone mineral density with a polymorphism of the peroxisome proliferator-activated receptor gamma gene: PPARgamma expression in osteoblasts. Biochem Biophys Res Commun 260: 122-126. [CrossRef]

- $\quad$ Rhee EJ, Oh KW, Lee WY, Kim SY, Oh ES, Baek KH, Kang MI, Kim SW (2005). The effects of C161-->T polymorphisms in exon 6 of peroxisome proliferator-activated receptor-gamma gene on bone mineral metabolism and serum osteoprotegerin levels in healthy middle-aged women. Am J Obstet Gynecol 192: 10871093. [CrossRef]

Rzonca SO, Suva L, Gaddy D, Montague DC, Lecka-Czernik B (2004). Bone is a target for the antidiabetic compound rosiglitazone. Endocrinology 145: 401-406. [CrossRef]

Sahmani M, Gholami A, Azarkeivan A, Darabi M, Ahmadi MH, Sabet MS, Najafipour R (2013). Peroxisome proliferator-activated receptor- $\gamma$ Pro12Ala polymorphism and risk of osteopenia in $\beta$-thalassemia major patients. Hemoglobin 37: 564-573. [CrossRef]

- Stunes AK, Westbroek I, Gustafsson BI, Fossmark R, Waarsing JH, Eriksen EF, Petzold C, Reseland JE, Syversen U (2011). The peroxisome proliferator-activated receptor (PPAR) alpha agonist fenofibrate maintains bone mass, while the PPAR gamma agonist 
pioglitazone exaggerates bone loss, in ovariectomized rats. BMC Endocr Disord 11: 11. [CrossRef]

- Szanto A, Nagy L (2008). The many faces of PPARgamma: antiinflammatory by any means? Immunobiology 213: 789-803. [CrossRef]

- Takano H, Komuro I (2009). Peroxisome proliferator-activated receptor gamma and cardiovascular diseases. Circ J 73: 214-220. [CrossRef]

- $\quad$ Tamaki J, Iki M, Morita A, Ikeda Y, Sato Y, Kajita E, Kagamimori S, Kagawa Y, Yoneshima H. (2010). Peroxisome proliferator-activated receptor gamma polymorphism is related to peak bone mass: the JPOS study. Osteoporos Int 21: 321-329. [CrossRef]

- Temelkova-Kurktschiev T, Hanefeld M, Chinetti G, Zawadzki C, Haulon S, Kubaszek A, Koehler C, Leonhardt W, Staels B, Laakso M (2004). Ala12Ala genotype of the peroxisome proliferator-activated receptor gamma2 protects against atherosclerosis. J Clin Endocrinol Metab 89: 4238-4242. [CrossRef]

- Touyz RM, Schiffrin EL (2006). Peroxisome proliferator-activated receptors in vascular biology-molecular mechanisms and clinical implications.Vascul Pharmaco/ 45: 19-28. [CrossRef]

- Wang XL, Oosterhof J, Duarte N (1999). Peroxisome proliferatoractivated receptor gamma $\mathrm{C} 161 \rightarrow$ T polymorphism and coronary artery disease.Cardiovasc Res 44: 588-594. [CrossRef]

- Wang Y, Sugita N, Yoshihara A, Iwasaki M, Miyazaki H, Nakamura K, Yoshie H (2013). Peroxisome proliferator-activated receptor (PPAR) Y polymorphism, vitamin D, bone mineral density and periodontitis in postmenopausal women. Oral Dis 19: 501-506. [CrossRef]
World Health Organization Study Group (1994). Assesment of fracture risk and its application to screening for postmenopausal osteoporosis. World Health Organ Tech Rep Ser 843: 1-129.

Yen CJ, Beamer BA, Negri C, Silver K, Brown KA, Yarnall DP, Burns DK, Roth J, Shuldiner AR (1997). Molecular scanning of the human peroxisome proliferator activated receptor gamma (hPPAR gamma) gene in diabetic Caucasians: identification of a Pro12Ala PPAR gamma 2 missense mutation. Biochem Biophys Res Commun 241: 270-274. [CrossRef]

- Yilmaz-Aydogan H, Kurnaz O, Kucukhuseyin O, Akadam-Teker B, Kurt O, Eronat AP, Tekeli A, Bugra Z, Ozturk O (2013). Different effects of PPARA, PPARG and ApoE SNPs on serum lipids in patients with coronary heart disease based on the presence of diabetes. Gene 523: 20-26. [CrossRef]

- Yilmaz-Aydogan H, Kurnaz O, Kurt O, Akadam-Teker B, Kucukhuseyin O, Tekeli A, Isbir T (2011). Effects of the PPARG P12A and C161T gene variants on serum lipids in coronary heart disease patients with and without Type 2 diabetes. Mol Cell Biochem 358: 355-363. [CrossRef]

- $\quad$ Yue H, He JW, Zhang H, Hu WW, Hu YQ, Li M, Liu YJ, Wu SH, Zhang ZL (2010). No association between polymorphisms of peroxisome [corrected] proliferator-activated receptor-gamma gene and peak bone mineral density variation in Chinese nuclear families. Osteoporos Int 21: 873-882. [CrossRef]

Zhang ZF, Yang N, Zhao G, Zhu L, Wang LX (2012). Association between the Pro12Ala polymorphism of peroxisome proliferatoractivated receptor gamma 2 and inflammatory bowel disease: a meta-analysis. PLoS One 7: e30551. [CrossRef] 